\title{
Studies on Indoor Air Pollution: 7. Indoor Plants and Air Borne Bacteria
}

\author{
Koriesh, E. M.; I. H. Abo-Elsoud" and M. M. Hefni \\ Horticulture Department, Faculty of Agriculture, Suez Canal University, 41522 Ismailia, Egypt
}

Received: $1 / 9 / 2016$

\begin{abstract}
This research is a trial to demonstrate a range of capacities of some indoor plants to improve indoor air quality (IAQ) through their role in reducing total number of indoor microbiome. Besides to improve oxygen content and unipolarity coefficient factor (UCF). Plant materials were Aspidistra elatior; Chlorophytum comosum; Dracaena fragrans; Dracaena marginata; Epipremnum aureus and Syngonium podophyllum. Results revealed that the higher impact of plants on the bacteria was observed with Dracaena marginata plant and the less impact to Dracaena fragrans plant. Oxygen percentage and UCF were higher with the presence of indoor plants than those in control treatment.
\end{abstract}

Keywords: air microbiome, airborne bacteria, indoor plants, unipolarity coefficient factor, indoor air quality

\section{INTRODUCTION}

Indoor environments provide new habitats and residence to numerous microbial communities comprising possibly hundreds of individual bacterial, archaeal and fungal species including diverse viruses, which can result in respiratory disorders and other adverse health effects (Berg et al., 2014). Houseplants improve the quality of indoor air. There are many substances of plant origin as phytoncides, which express diverse biostatic activity in relation to microbiome (Alsam et al, 2009). Phytoncides ionize the oxygen in the air, thus increasing its biological activity, promote settling of dust particles, reduce the electric index of air pollution and neutralize microorganisms in the air (Lim et al., 2015). Indoor microorganisms affect human health as allergenic agents (Hanski et al., 2012). Little is known about the impact of houseplants on indoor microbes, it is our opinion that both outside and inside plants are of importance. Some of indoor plants have demonstrated filtration properties that reduce the presence of airborne bacteria.

Plants that reduce indoor bacteria improve the overall indoor air quality (IAQ). In general, no plant is able to completely eliminate bacteria (Koriesh, 2001; Wolverton and Wolverton, 1996). Geraniums and begonias reduce the concentration of microorganisms in the ambient air by $43 \%$, Cyperus by $59 \%$, Chrysanthemum parviflorum by $66 \%$ (Sinicina et al. 2013).

The objective of this study was to investigate the effect of some indoor foliage plants on the total number of airborne bacteria and the impact of these plants on UCF.

Results of Sinicina et al. (2013) revealed that phytoncides inhibit the growth of microorganisms, thus may play an important role in plant resistance to pathogens. Different Phytoncides vary in their antimicrobial action, and microorganisms also differ in their sensitivity to these compounds. The following plants contain volatile organic compound (VOC) which can work as antimicrobial compounds; including Aspidistra (Koketsu et al., 1996), Chlorophytum (Alisha et al. 2014), Dracaena (Saiyood et al., 2010) Epipremnum aureus and Syngonium podophyllum (Kumar et al., 2014; Sonawane et al., 2011).

Air ion concentrations have different effects on human health and microorganisms (Perez et al., 2013).
This effect depends on proportions of positive and negative ions (Nakane, 2003). These proportions are characterized by UCF: $K=\mathrm{n}^{+} / \mathrm{n}^{-}$, where $\mathrm{n}+$ and $\mathrm{n}$ - mean concentration of positive and negative cluster ions (Sinicina et al., 2013).

The objective of this study was to investigate the effect of some indoor foliage plants on the total number of airborne bacteria and the impact of these plants on UCF.

\section{MATERIALS AND METHODS}

Airborne bacteria communities were sampled at the Horticulture Department, Suez Canal University, Egypt, in 2014 and 2015. A sample was collected from office air and from about 0.2 square meter of double wall glass growth chamber to keep indoor temperature under lower fluctuations. Deposition technique as mentioned by Abdul Wahid et al. (1996) has been adopted for studying air spores. Nutrient agar medium was used, (Lab M. Limited, UK). Petri dishes were incubated for $48 \mathrm{~h}$ at $25^{\circ} \mathrm{C}$ and bacteria were incubated for $48 \mathrm{~h}$ at $37^{\circ} \mathrm{C}$.

Three Petri dishes were used for each treatment, the experiment were repeated at the same place. Bacteria colonies were calculated manually. The selected plants were allowed to grow in an aerated glass chamber (about $0.25 \mathrm{~m}^{3}$ ) with $10 \mathrm{~cm}$ computer fan. Inside this chamber, air ion counter and air oxygen meter instruments were installed.

The selected plants were: Aspidistra elatior Blume; Chlorophytum comosum (Thunb), Jacques; Dracaena fragrans (L.) Ker Gawl; Dracaena reflexa Lam.; Epipremnum aureus (Linden and Andre) G.S. Bunting and Syngonium podophyllum Schott. Plants were grown in a $25 \mathrm{~cm}$ plastic pots filled with 3:1 sand and peat-moss. Every plant in a plastic pot was wrapped and transferred to the growth chamber. The growth chamber was closed and supplied with 7 watt LED bulb for $16 \mathrm{~h}$ per day.

The air sampling was performed for 30 minutes during regular working hours (between 10:00 and 12:00 am) on weekdays according to the techniques mentioned by Abdul Wahid et al. (1996) for studying air spores. Control sample was taken from staff room inside growth room when it was open. Samples were taken from the closed growth room and after 24 hours 
from leaving every plant inside under light regime as 16 $\mathrm{h}$ light from 7 watt LED bulb. At zero time and after 24 hours from leaving plants, a record of both air ions using air ion counter (Alphalab, Inc. USA) or oxygen using oxygen meter was made.

A Foobot instrument model FBT0002000 (DaoHaus Technologies) was used to monitor living space with VOC or not in presence of each plant.

\section{RESULTS AND DISCUSSION}

It is clearly shown from Table (1) and graphics (2) that the presence of studied plants in the growth chamber, was the reason for the lack of total number of colonies of airborne bacteria. The higher impact on the bacteria, greater impact to $D$. marginata plant was obtained with less impact to $D$. fragrans plant.

This may be referred to the presence of negative air ions as UCF (Charry, 1984). The positive value of the UCF was recorded in the control treatment was +1.025 , meanwhile, the rest of the treatments, which have plants, showed a negative UCF values (Table 1). It is clearly shown that these plants produce different concentrations of negative ions as well as the oxygen concentrations (Table 1 and diagram 2).

In this concern, Charry (1984) concluded that air ion concentrations have different effects on microorganisms. Sinicina et al. (2013) added that the indoor air contains less small oxygen ions than the natural air. The results in table (1) indicated that oxygen concentrations increased with plant, so the indoor air quality was improved. On the other hand, Metallic (2012) reviewed that plants emit phytoncides increasing its biological activity and neutralize microorganisms in the air which inhibit the growth of microorganisms (Sinicina et al. 2013).

Our results indicate that the air quality of office is far from being ideal. However, it can be significantly improved with the help of house plants. Indoor phytodesign or architectural arrangement design with specific selected plants is a scientifically grounded method of using plants for the improvement of indoor air quality. Also, its functions include the purification of the air from dust and chemical compositions which have positive influence on human organism, creating a nice and comfortable environment.

Table (1): Effects of the selected plants on bacteria found in the growth chamber, UCF and air oxygen percentage

\begin{tabular}{lcccc}
\hline Plants & Bacteria & $\begin{array}{c}\text { \% of residual } \\
\text { bacteria }\end{array}$ & $\mathbf{U C F}^{+} / \mathbf{n}^{-}$ & Oxygen \% \\
\hline Control (in) & $102.33+1.86$ & 100 & 1.025 & 19.5 \\
A. elatior & $010.67+0.33$ & 1.2 & -0.1158 & 22.4 \\
C. comosum & $007.67+2.33$ & $\mathbf{4 . 9}$ & -1.0948 & 22.75 \\
D. fragrans & $016.33+5.24$ & $\mathbf{1 6 . 5}$ & -0.9000 & 22.4 \\
D. marginata & $004.00+0.58$ & 3.4 & -2.1707 & 23.6 \\
E. aureus & $010.67+3.53$ & 9.7 & -1.1065 & 22.35 \\
S. podophyllum & $011.00+1.00$ & 1.2 & -1.2911 & 22.55 \\
\hline
\end{tabular}

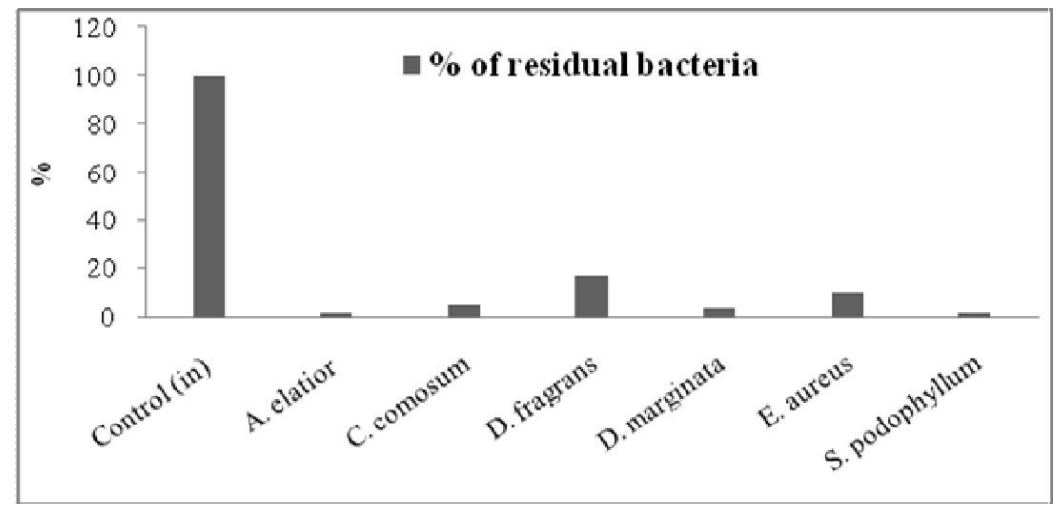

Diagram (1): reduction percentage of airborne bacteria as affected by the indoor plants compared to control as $100 \%$ 


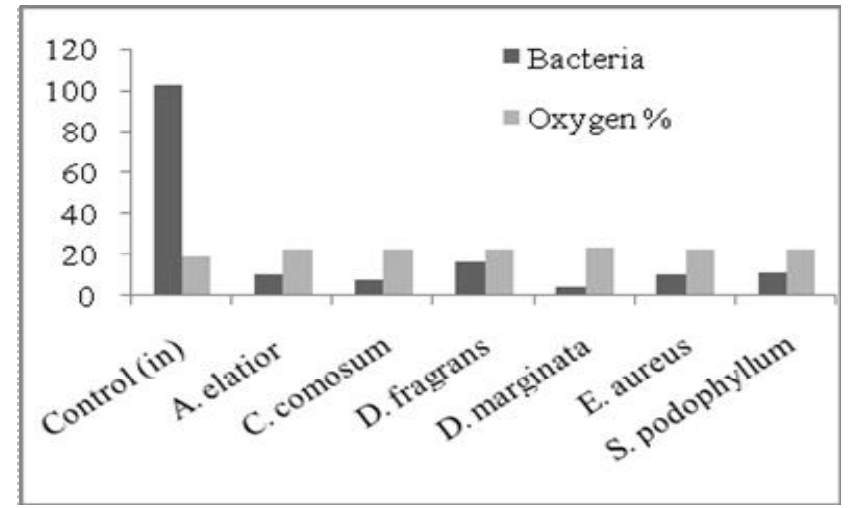

Diagram (2): Total colonies of airborne bacteria in relation to oxygen percentage produced by the indoor plant

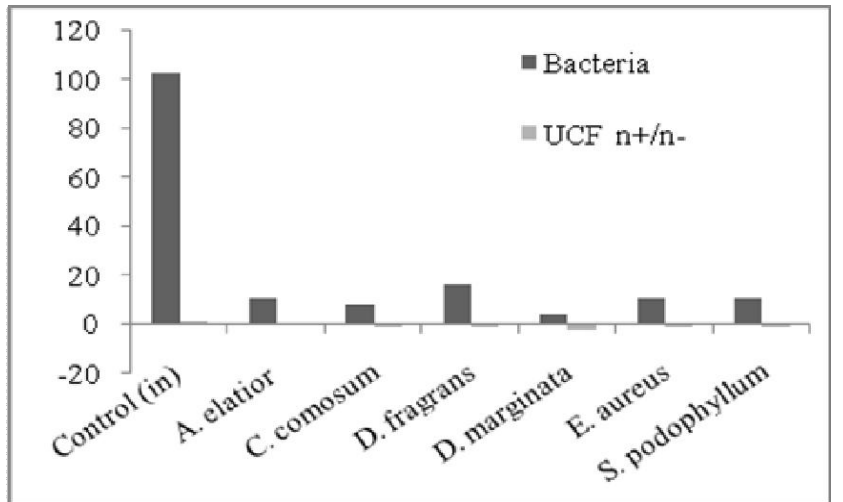

Diagram (3): Total colonies of airborne bacteria in relation to UCF for every used indoor plant

Table (2): Production of VOC by plants

Plants

VOC

\% of residual bacteria

$\begin{array}{lcc}\text { A. } \text { elatior } & - & 1.2 \\ \text { C. } \text { comosum } & ++ & 4.9 \\ \text { D. fragrans } & ++ & \mathbf{1 6 . 5} \\ \text { D. marginata } & + & 3.4 \\ \text { E. } \text { aureus } & + & 9.7 \\ \text { S. podophyllum } & + & 1.2\end{array}$

\section{REFERENCES}

Abdul Wahid, O. A., A. F. Moustafa and A. M. Moustafa (1996). Fungal population in the atmosphere of Ismailia city. Aerobiologia, 12: 249-255.

Alisha, B., A. Shoaib and S. L. Harikumar (2014). Chlorophytum comosum (Thunberg) Jacques: a review. Int. Res. J. Pharm.. 5: 546-549.

Alsam, F., K. Rehman, M. Asghar and M. Sarwar (2009). Antibacterial activity of various phytoconstituentes of neem. Pak. J. Agri. Sci., 46(3): 209-213.

Berg, G., A. Mahnert and C. Moissl-Eichinger (2014). Beneficial effects of plant-associated microbes on indoor microbiomes and human health? Front Microbiol., 5: 15.

Charry J. M. (1984) Biological effects of small air ions: A review of findings and methods. Environmental Research, 34: 351-389.

Hanski, I., L. Von Hertzen, N. Fyhrquist, K. Koskinen, K. Torppa and T. Laatikainen (2012). Environmental biodiversity, human microbiota, and allergy are interrelated. Proc. Natl. Acad. Sci. U.S.A., 109: 8334-8339.

Koketsu, M., M. Kimand and T. Yamamoto (1996). Antifungal activity against food-borne fungi of Aspidistra elatior Blume. J. Agric. Food Chem.., 44: 301-303
Koriesh, E. M. (2001). Studies on indoor pollution. I. Indoor plants and bacteria. The Fifth Arabian Horticulture Conference, Ismailia, Egypt, 2: 337-344.

Kumar, S., R Kumar, A. Dwivedi and A. K. Pandey (2014). In vitro antioxidant, antibacterial, and cytotoxic activity and in Vivo effect of Syngonium podophyllum and Eichhornia crassipes leaf extracts on isoniazid induced oxidative stress and hepatic markers. BioMed Research International, 18: 281-283. http://dx.doi.org/10.1155/2014/459452

Lim, L., Y. Jang, J. Yun and H. Song (2015). Phytoncide, nanochemicals from Chamaecyparis obtusa, inhibits proliferation and migration of vascular smooth muscle cells. Journal of Nanoscience and Nanotechnology, 15: $112-115$

Metallic, D. (2012). Potted Plants Reduce Indoor Air Pollution. http://www.idoincorporated.com/pot ted- plants-reduce-indoor-air-pollution/

Nakane, N. (2003). Stress-reducing effect of negative air ions. Research Report. R \& D Review of Toyota CRDL., 38: 50-54. http://www.tytlabs.com/english/review/rev382 epdf/e382 050nakane.pdf

Perez, V., D. D. Alexander and W. H. Bailey (2013). Air ions and mood outcomes: A review and meta-analysis. BMC Psychiatry. 15: 13-29. 
Saiyood, S., A. S. Vangnai, P. Thiravetyan and D. Inthorn (2010). Bisphenol a removal by the dracaena plant and the role of plant-associating bacteria. J . Hazard Mater.. 15: 777-85.

Sinicina, N., A. Skromulis and A. Martinovs (2013). Impact of microclimate and indoor plants on air ion concentration. Environment Technology. Resources Proceedings of the $9^{\text {th }}$ International Scientific and Practical Conference, 1: 66-72.
Sonawane, C. S., D. M. Jagdale, S. D. Patil, L. J. Patil and V. J. Kadam (2011). Phytochemical screening and in vitro antimicrobial activity studies of Epipremnum aureum Linn. leaves extracts. Der. Pharmacia Sinica., 2: 267-272. www.pelagiaresearchlibrary.com

Wolverton, B. C. and J. D. Wolverton (1996). Interior plants: their influence on airborne microbes inside energy-efficient buildings. J. Mississippi Aca. of Sci., 41: 99-105.

\section{دراسات على تلوث الهواء الداخلي: 11 ـ النباتات الداخلية والبكتريا المحمولة في الهواء \\ عيد محمد قريش ، إسلام حسن أبو السعود" ، ، محمود مختار حفني

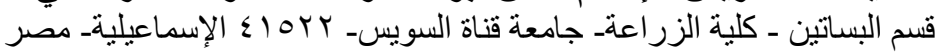

هذا البحث هو محاولة للتعرف علي مدي قدرة بعض النباتات المنزلية في تقليل أعداد البكتريا المحمولة في الهواء الداخلي

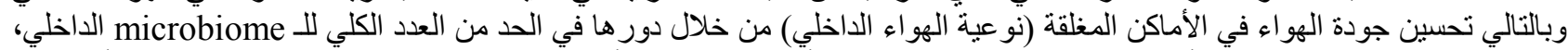
بالإضافة إلى تحسين محتوى الأوكسين وتحسين عامل معامل أحادية القطب للائيونات (UCF). Aspidistra elatior

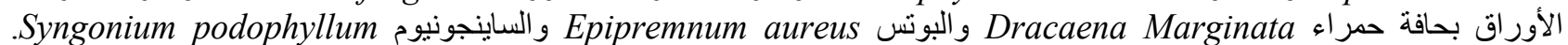

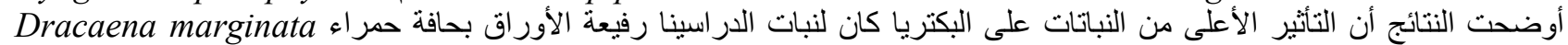
و الأقل تأثير الدر اسينا عريضة الأور اق. كانت نسبة الأكسجين و UCF أعلى مع وجود النباتات الداخلية من تلك الموجودة في معاملة المقارنة 